\title{
Evaluation of Wear Properties of Heat-treated Al 7075/Graphite Powder/Bagasse ash Hybrid Metal Matrix Composites
}

\author{
'Maibusab'1 , H K Shivanand², Madhu M.G ${ }^{3}$, Shivaraj H.A' ${ }^{1}$, Sumana B G ${ }^{4}$ \\ ${ }^{1}$ P.G Scholar, Department of Mechanical Engineering, University Visveswarayya College of Engineering, \\ Bengaluru, Karnataka, India \\ ${ }^{2}$ Professor (Department of Mechanical Engineering), University Visveswarayya College of Engineering, \\ Bengaluru, Karnataka, India. \\ ${ }^{3}$ Lecturer, Department of Mechanical Engineering, Government polytechnic Udupi-576104, Karnataka, India. \\ ${ }^{4}$ Assistant Professor (Department of Mechanical Engineering), Government Engineering College, Hassan, \\ Karnataka, India. \\ ${ }^{*}$ Contact Author e-mail: maibu.uvce@gmail.com
}

\begin{abstract}
This research work investigated the influence of graphite powder on the wear behavior of $\mathrm{Al} 7075 / \mathrm{Graphite}$ Powder (Gr)/Bagasse ash (BA) hybrid composite. The investigation reveals the effectiveness of incorporation of graphite powder in the composite for gaining wear reduction. The Al 7075 (Aluminium alloy 7075) reinforced with graphite powder and Bagasse ash were investigated. The conventional liquid casting technique was used for the fabrication of composite material and subjected to T6 heat treatment. The reinforcement content was chosen as 1,3 , and $5 \mathrm{wt}$. \% of graphite powder to identify its potential for self-lubricating property under dry sliding conditions. Hybrid composite is processed at $1 \mathrm{wt} \%$ of $\mathrm{Gr}$ with 2, 4 and $6 \mathrm{wt} \%$ of BA. The effect of load on dry sliding wear rate and coefficient of friction performance of Al 7075 casting alloy and its composites was evaluated by using a pin-on-disc with two different loads with constant speed at room temperature. Wear tests were conducted by using pin on disc apparatus to evaluate the tribological behaviour of the composite and to determine the optimum content of graphite powder for its minimum wear rate. The wear rate decreases with addition of graphite powder content and reaches its minimum at $5 \mathrm{wt}$. \% graphite. The coefficient of friction decreases with addition of graphite content and was found to be minimum at wt. $5 \%$ graphite. The wear properties of the hybrid composites containing graphite exhibited the superior wear-resistance properties.
\end{abstract}

Keywords : Wear rate, Friction, Al7075, Bagasse ash, Graphite powder (Gr)

\section{INTRODUCTION}

This research is a compilation of the overview of the research work and characteristic aspects of the evaluation of the composite materials fabricated utilizing Aluminium as the matrix phase and
Graphite powder and Bagasse ash as the reinforcement phases.

The utilization of advanced performance of wear resistance material for various tribological function in the development of hybrid composite materials. The use of ceramic reinforcement in monolithic $\mathrm{Al}$ matrix, composite has increases in mechanical and 
tribological properties appreciably. The recent type of composites are known as hybrid composites, in which properties of more than one suitable reinforcement have been exploited to improve the overall properties of composite including tribological properties[1-2]. This paper give a current development about tribological properties of hybrid composites

The recent development for potential applications is to optimize the mechanical properties and tribological properties of MMCs. AMMCs (Aluminum metal matrix composites) reinforced with discontinuous dispersoid in the forms of fibers, whiskers, and particulates reveal amplify strength significance at good wear resistance, low coefficient of friction, low thermal expansion and stiffness compared to base alloys. AMMCs has application in automobile engine block pistons and brake drum. These automotive engine components are subjected to dry sliding wear [3-4]. Wear resistance of aluminum ( $\mathrm{Al}$ ) alloys are improved by introducing particulate reinforcement such as $\mathrm{SiC}[5-7], \mathrm{Al}_{2} \mathrm{O}_{3}[7-$ 8], TiC [6, 9], Beryl [10], Hence AMMCs are possible materials for tribological application [10-14]. The level of enhancement in the dry sliding wear resistance of particulates reinforced Al- matrix composites depends on type of reinforcement used, manufacturing technique and contact condition. The interfacial bond strength, mechanical properties of matrix and reinforcement are essentially affect on wear resistance of composites [4, 7 , and 11$]$. The two major types of tribological factor control the friction and wear behaviour of $\mathrm{Al}$ based composites are physical and mechanical factors [12-13]. Many researchers and investigators stated that, wear performance of $\mathrm{SiC}, \mathrm{Al}_{2} \mathrm{O}_{3}, \mathrm{Gr}$ and $\mathrm{BA}$ particles reinforced composites are shows better tribological properties hybrid composites.

Kok and Ozdin[14] investigated the effect of $\mathrm{Al}_{2} \mathrm{O}_{3}$ particle content and size on the wear behavior of
$\mathrm{Al}_{2} \mathrm{O}_{3}$ particle reinforced 2024 aluminium alloy composites fabricated by vortex method. Surappa et al. [15] have studied the influence of 5 vol. $\% \mathrm{Al}_{2} \mathrm{O}_{3}$ particles addition on the wear resistance of hyper eutectic $\mathrm{Al}-\mathrm{SiC}$ alloys.

Yu et al. [16] have studied the effects of applied load and temperature on the dry sliding behavior of $\mathrm{Al}$ 6061/SiC composites, Liang et al. [17] have identified that the MMCs containing $\mathrm{SiC}$ particles exhibit improved wear resistance. Reda et al. [18] and Clark et al. [19] have reported that Pre-aging at various temperatures improves the hardness, tensile properties and electrical resistivity of $\mathrm{Al} 7075$.

Kim et al. [20] concluded that the hardness of aged $\mathrm{Al}$ 7075 alloy was increased. Doel and Bowen [30] have reported the improved tensile strength and lower ductility of $\mathrm{Al} 7075$ reinforced with $\mathrm{SiC}$ particles than that of unreinforced, Komai et al. [21] have identified superior mechanical properties of $\mathrm{Al} 7075-\mathrm{SiC}$ composites.

Generally lubricant is externally added to reduce the wear. This poses the problem when the materials need the periodic applications of lubricant particularly to wear parts which are difficult to access. For such applications self-lubricating materials are preferred because the solid lubricant contained in them can be automatically released during the wear process to reduce the wear. Graphite is one of the most widely used solid lubricant materials. Earlier researchers [22-25] have already focused their investigation on applications of aluminium graphite composite. There are also earlier reports from some investigators [26-27] who identified the trend that aluminium graphite composite containing the small amount of graphite exhibit superior wear properties over the base alloys. The limitation with the aluminium graphite composite is in using graphite as a solid lubricant whose introduction results in the loss of strength of the composite. 


\section{MATERIALS PROCUREMENT}

\section{ALUMINIUM 7075 ALLOY}

Aluminum alloy 7075 is an aluminum alloy, with zinc as the primary alloying element. It is strong with strength and has good fatigue strength and average machinability. Alloy7075 is heavily utilized by the aircraft and ordnance industries because of its superior strength.

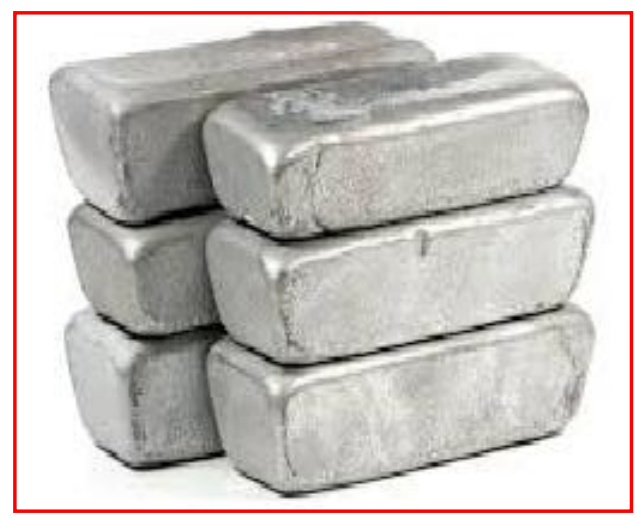

Fig.1: Aluminum 7075 Ingots

\section{GRAPHITE POWDER}

Graphite is a form of elemental carbon. Graphite is used in several fields due to its electrical conductivity and chemical properties. Synthetic graphite is a manmade essence contrived by the heavy temperature processing of amorphous carbon materials. The types of amorphous carbon used as precursors to graphite are many and can be consequent from coal, petroleum, or natural and synthetic organic materials. In a few cases graphite can constant be manufactured by the direct precipitation of graphitic carbon from pyrolysis of a carbonaceous gas such as pyrolytic graphite (acetylene). One important commonality between all graphite precursors is that they must contain carbon.

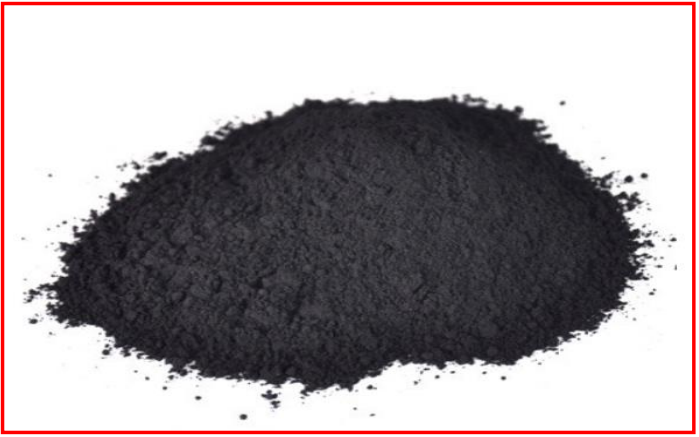

Fig.3: Graphite powder

\section{BAGASSE-ASH}

Sugarcane bagasse ash is a byproduct of sugar factories found after burning sugarcane bagasse which itself is found after the extraction of all economical sugar from sugarcane. It is an industrial waste which is used worldwide as fuel in the same sugarcane industry. These sugarcane bagasse ashes (SCBA) have been chemically, physically and miner logically characterized in order to evaluate the possibility of their use as a cement replacing material in concrete industry.

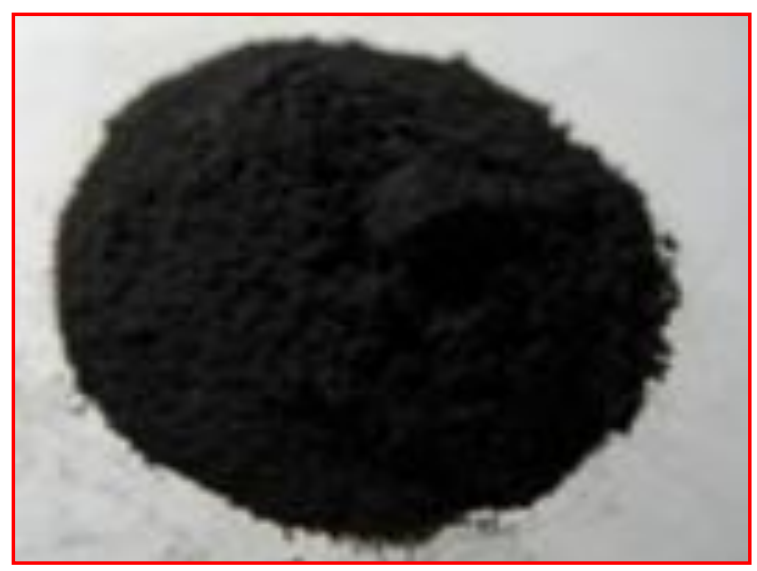

Fig.2: Fine Bagasse Ash

\section{EXPERIMENTAL DETAILS}

Composite is picked as matrix material inferable from its wide application in numerous designing divisions including car and aviation areas. Further, this composite displays great quality and formability. Graphite exhibits the properties such as high rigidity, low thickness, low rubbing and wear resistance and high thermal conductivity. The mixture structure of 
composites utilized as a part of the present study is accounted for in the Table 1. Both Graphite and Al7075 combinations were acquired from Fenfe expense Metallurgical, Harohalli, Bangalore, India. What's more, bagasse fiery debris is found in mandya sugar stick industrial facility.

The composites are manufactured by following steps:

1. Casting.

2. Machining.

3. Testing.

\section{Casting}

The microstructure of any material is a complex function of the casting process, subsequent cooling rates. Therefore, composites fabrication is one the most challenging and difficult task. Stir casting technique of liquid metallurgy was used to prepare $\mathrm{Al}$ 7075 and $\mathrm{Al} 7075$ Hybrid composites.

Ingots of Al-7075 amalgam are set in heater and heater is warmed up to $800^{\circ} \mathrm{C}$. Refer Fig 4 Ascertained amounts in weight rate are filled in the liquid Al-7075 and mixed utilizing zirconium covered spoon. All around mixture composites are filled in the die, which is as demonstrated in the fig 4 . The melting range of $\mathrm{Al} 7075$ alloy is of $700-800^{\circ} \mathrm{C}$. A known quantity of $\mathrm{Al} 7075$ ingots were loaded into the Graphite crucible of the furnace for melting. The melt was super-heated to a temperature of $800^{\circ} \mathrm{C}$ and maintained at that temperature. The molten metal was then degassed using Hexo-Chloro ethane tablets for about 8min.

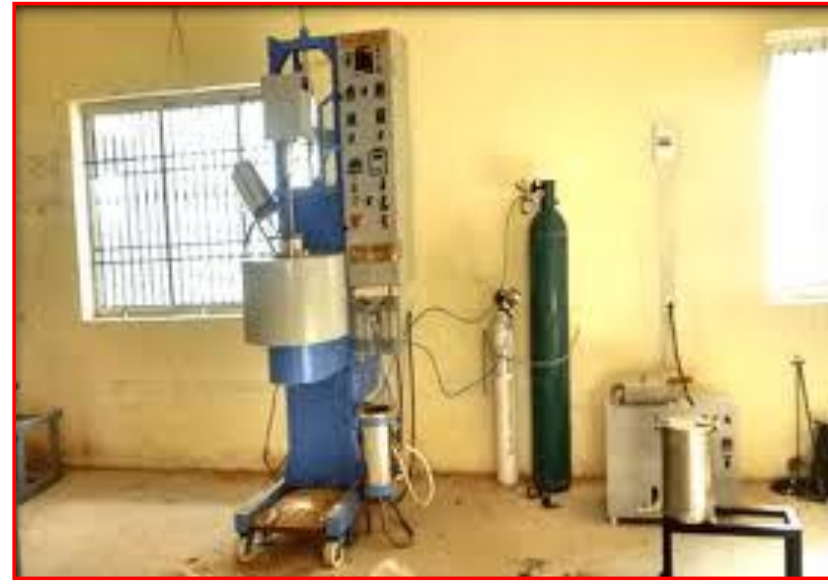

Fig. 4: A stir casting setup, consist of a Coke fired Furnace and a stirrer assembly, which was used to synthesize the composite.

Table 1: Percentage of Reinforcements.

\begin{tabular}{|c|c|c|c|}
\hline \multirow{2}{*}{ Specifications } & \multicolumn{3}{|c|}{ Reinforcements } \\
\cline { 2 - 4 } & $\begin{array}{l}\text { Al 7075 } \\
\text { in \% }\end{array}$ & $\begin{array}{l}\text { Graphite } \\
\text { Powder } \\
\text { in 0/ }\end{array}$ & $\begin{array}{c}\text { Bagasse } \\
\text { Ash in \% }\end{array}$ \\
\hline A1G2B & 97 & 1 & 2 \\
\hline A1G4B & 95 & 1 & 4 \\
\hline A1G6B & 93 & 1 & 6 \\
\hline A3G2B & 95 & 3 & 2 \\
\hline A3G4B & 93 & 3 & 4 \\
\hline A3G6B & 91 & 3 & 6 \\
\hline A5G2B & 93 & 5 & 2 \\
\hline A5G4B & 91 & 5 & 4 \\
\hline A5G6B & 89 & 5 & 6 \\
\hline
\end{tabular}

\section{Machining}

After the casting is done, castings are machined according to ASTM standards on highly sophisticated lathe. The turning operation carrying on lathe is shown in Fig 5. As per the ASTM standard G99-95 wear specimen is machined as shown in Fig-6. 


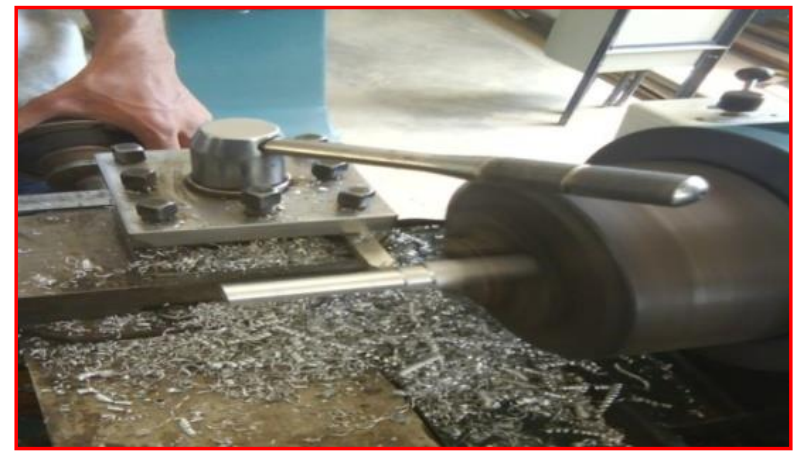

Fig 5 Turning operation carrying on lathe

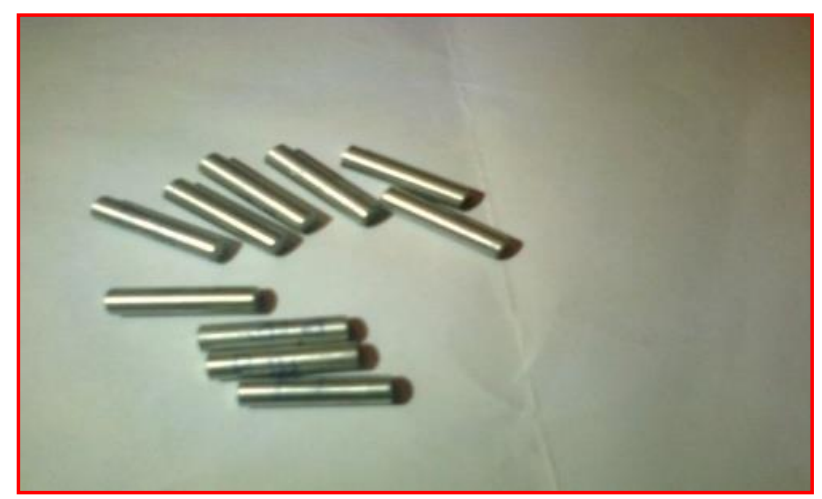

Fig 6 Wear test specimen

\section{Testing}

\section{Wear Test}

According to ASTM G99-95 standards, the wear tests were conducted using Pin-on-disc apparatus (Figure 7) at room temperature $\left(30^{\circ} \mathrm{C}\right)$ and humidity 60 $65 \%$.The tests were conducted at constant 300rpm sliding speed and $0.5 \mathrm{~kg}$ and $1 \mathrm{~kg}$ applied loads and with constant sliding distance $2637.600 \mathrm{~m}$. Pins with $6 \mathrm{~mm}$ diameter and $30 \mathrm{~mm}$ height were used for the Wear test. The surface of the pin was polished and was rotated against an OHNS(Oil Hardened Nickel Steel) disc which was heat treated to a hardness of 62 HRc. The wear tests were conducted after the initial run in period when the pin specimen was entirely in contact with the disc surface. The wear rate was calculated using weight loss method. The weight of the each specimen was measured using an electronic weighing balance with resolution of $\pm 0.1 \mathrm{mg}$ [2].

\begin{tabular}{|c|c|c|}
\hline Element & Symbol & $\begin{array}{l}\text { Composition \% } \\
\text { in Al 7075 }\end{array}$ \\
\hline Zinc & $\mathrm{Zn}$ & 5.4 \\
\hline Copper & $\mathrm{Cu}$ & 1.42 \\
\hline Manganese & $\mathrm{Mn}$ & 0.12 \\
\hline Magnesium & $\mathrm{Mg}$ & 2.42 \\
\hline Ferrite & $\mathrm{Fe}$ & 0.42 \\
\hline Chromium & $\mathrm{Cr}$ & 0.21 \\
\hline Aluminium & $\mathrm{Al}$ & Remaining \\
\hline
\end{tabular}

Table 2 Chemical composition of $\mathrm{Al} 7075$.

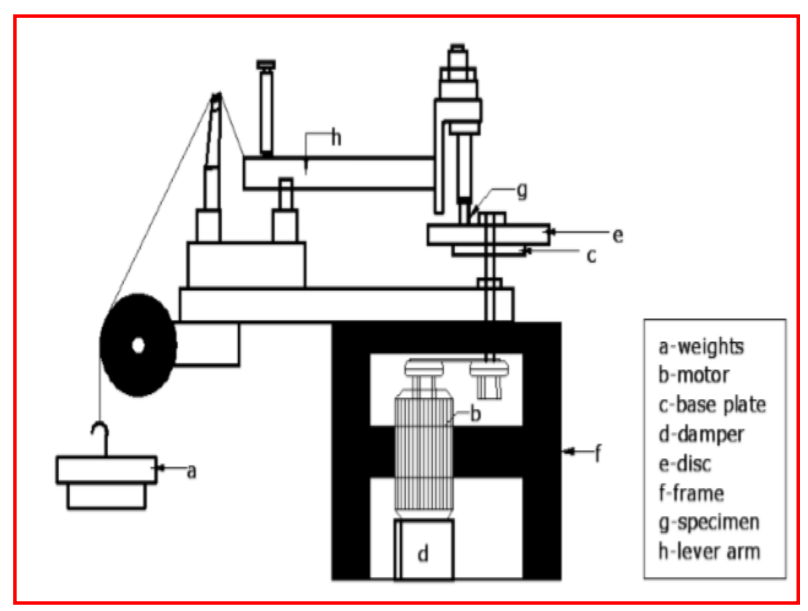

Fig.7 A schematic diagram of pin on disc apparatus

\section{HEAT TREATMENT}

\section{T6 Heat Treat Process}

T6 heat treatment of cast specimens offers increase in hardness and other mechanical properties, which is often required for many applications. The T6 heat treat is a two-step process. The castings are first allowed to cool naturally and are then heated at an elevated temperature in one of our high temperature ovens. After a set period of time the castings are quickly quenched. The castings are then moved to one of our low temperature ovens for the second step of the process.

In order to develop the correct balance of mechanical properties, it was thought essential to subject the test casting to an optimized thermal treatment (viz. solution heat treatment and quenching). Test samples of suitable length were solutionized in a heat 
treatment furnace for a temperature of $525^{\circ} \mathrm{C} \pm 50^{\circ} \mathrm{C}$ for duration of 5 hours. After solutionizing the samples were immediately quenched in water kept at room temperature, stored in the tanks below the furnace. The quenching was done strictly within 15 seconds of opening the furnace door.

The specimen (as cast condition) were subjected to the following heat treatment conditions.

The castings are first allowed to cool naturally and are then heated at an elevated temperature of $525^{\circ} \mathrm{C}$ for $5 \mathrm{hrs}$.

Quenching in water at a temperature of $60^{\circ} \mathrm{C}$

\section{RESULTS AND DISCUSSIONS}

\section{Wear rate and Coefficient of friction}

Wear rate and coefficient of friction of composites has observed experimentally based on effect of load and effect of reinforcement. Decreasing wear rate with increasing in load and reinforcement, increasing in wear rate with increasing in sliding speed and distance.

Wear loss is decreased with the increased reinforcement weight fractions at any applied load. Hence it is very much clear that shows in figure-2 (a) and (b) and figure 3 (a) and (b) can be concluded that wear resistance increased and friction decreased of hybrid composites with the increasing reinforcement fractions.
1. Effect of wt. \% of reinforcement (Graphite and Bagasse ash)

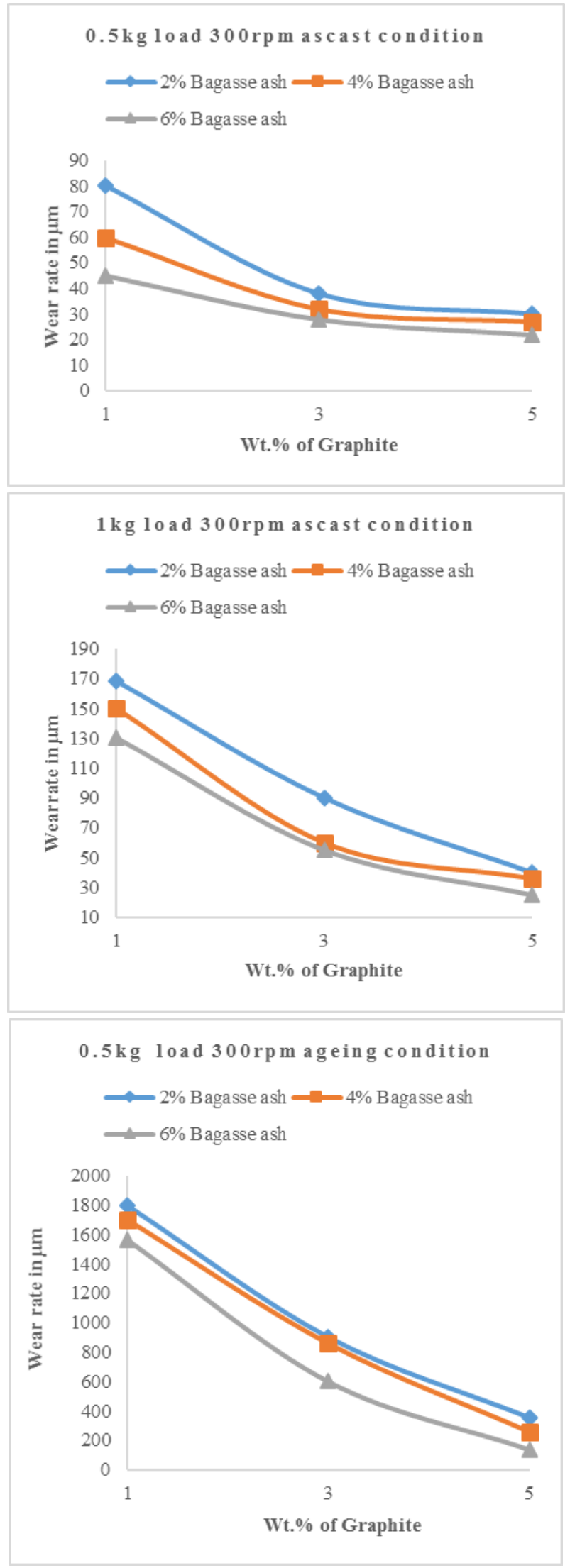




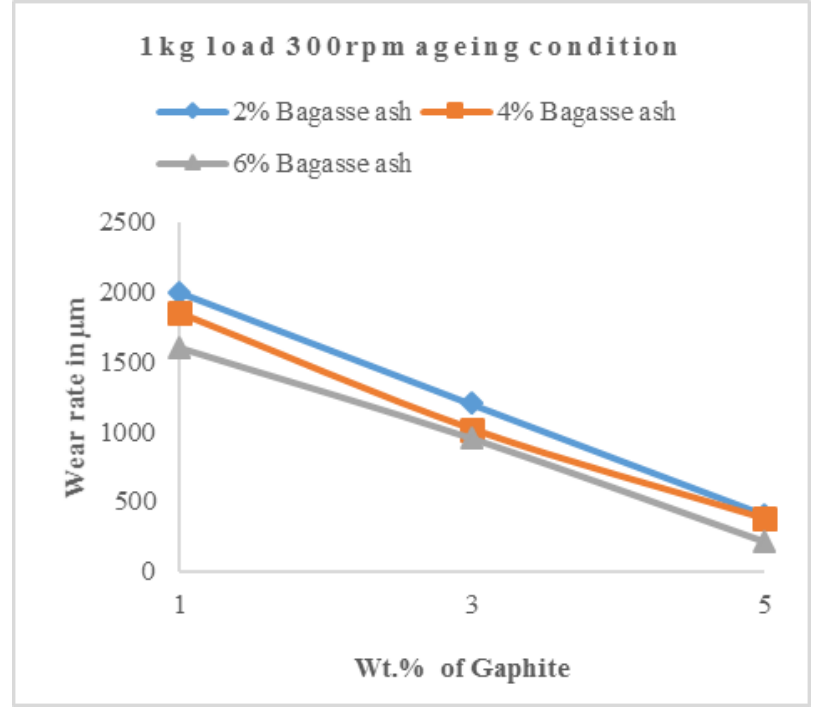

Figure 2 (a): Effect of Wt. \% of reinforcement on Wear Rate

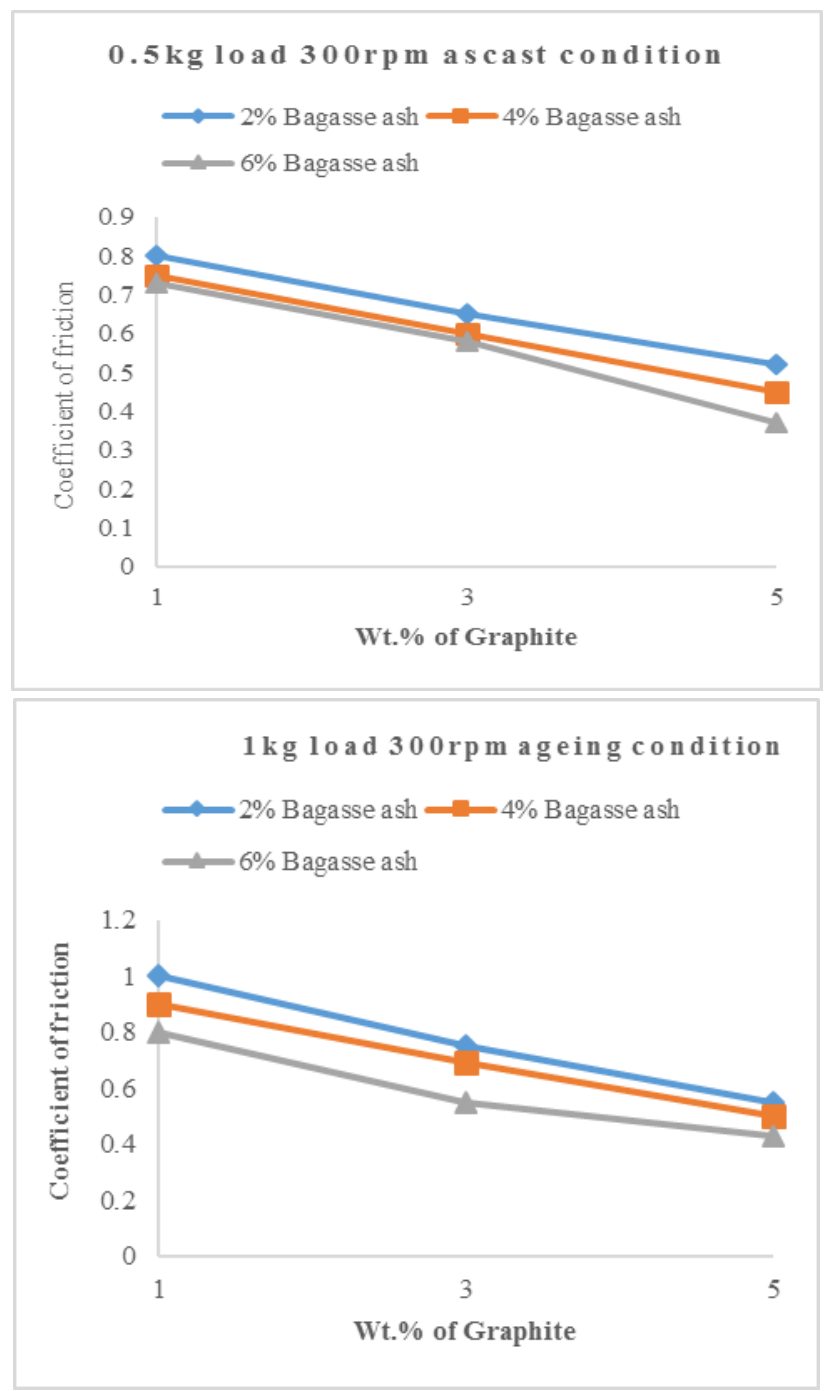

Figure 2 (b): Effect of Wt. \% of reinforcement on

\section{Effect of increasingload}

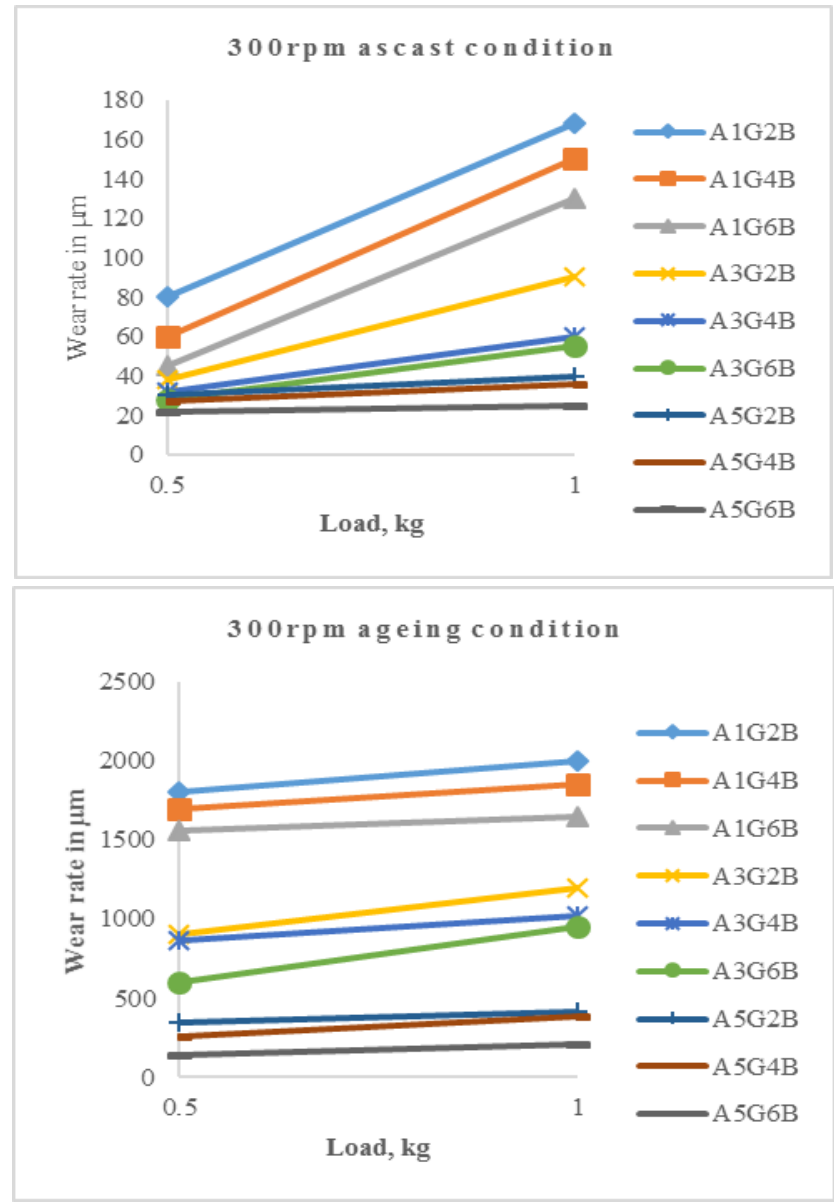

Figure 3 (a): Effect of Increasing load on Wear Rate

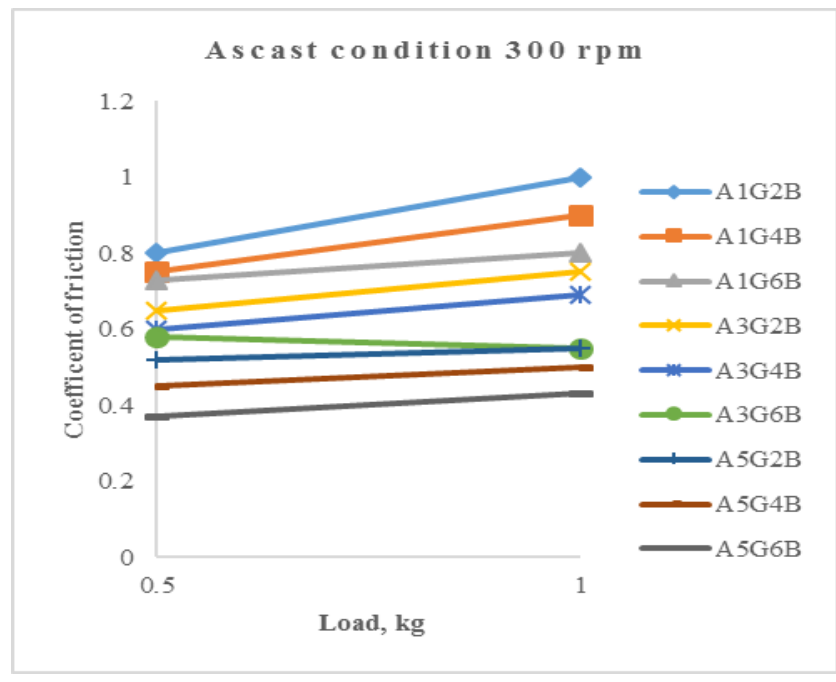




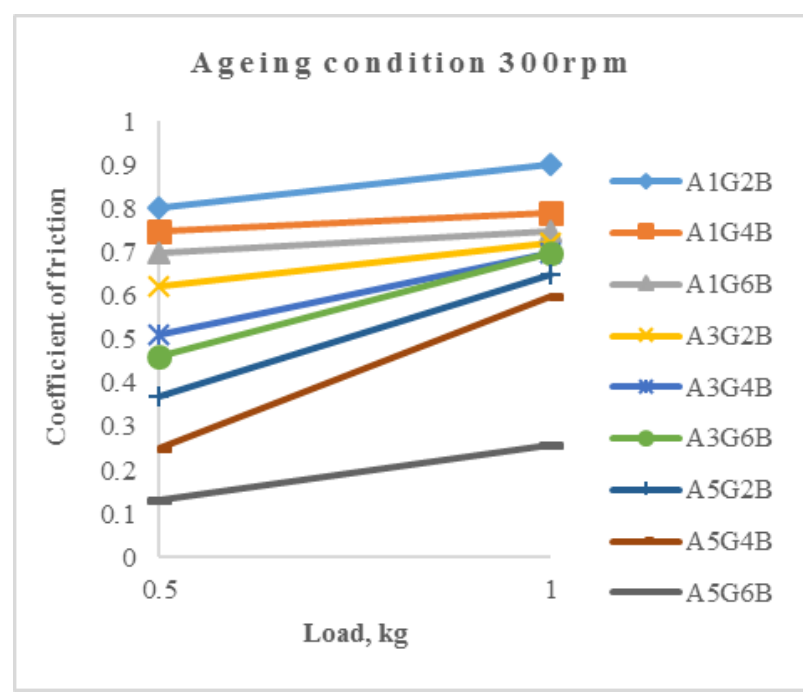

Figure 3 (b): Effect of Increasing load on Coefficient of Friction.

\section{CONCLUSION}

The addition of the reinforcements has resulted in a steady decreases in wear rate and coefficient of friction.

The wear rate reduces with increase in graphite content and it was found minimum at 5 wt. \% of graphite powder, which exhibits the superior wear properties

$>$ The effect of Graphite powder and Bagasse ash particles on the sliding wear resistance in $\mathrm{Al} 7075$ alloys varies with the applied load and speed.

$>$ Wear rate has been decreased as the ageing duration is increased. The wear resistance has been increased significantly for heat treated composites compared to as cast composites.

$>$ Coefficient of friction is reduces as content of graphite powder increases.

\section{REFERENCES}

[1]. Mohammed Imran and Dr. A.R Anwar Khan "Friction and Wear Properties of Al7075-BAGr Hybrid Composites" (c) 2017 IJSRST Volume 3 | Issue 7 | Print ISSN: 2395-6011 | Online ISSN: 2395-602X
[2]. Baradeswaran, A., Perumal, E., "Wear and mechanical characteristics of Al 7075/Graphite composites," Composites: Part B (2013), (doi:http://dx.doi.org/10.1016/j.compositesb.201 3.08.073)

[3]. R. L. Deuis, Subramanian \& J. M. Yellupb, "Dry Sliding Wear of Aluminium Composites-A Review" Composites Science and Technology Vol. 57, 1997.

[4]. Bharat Kumar, Anil Parmar, DhavalGhoghalia, MandhataYadav, Samarth Bhaduwala "Wear Analysis of Aluminium Based Composites by Stir Casting Process: A Literature Review", International Journal of Innovative Research in Science, Engineering and Technology, Vol. 4, Issue 8, August 2015.

[5]. Riyadh A. Al-Samarai1, Haftirman, Khairel Rafezi Ahmad, Y. Al-Douri, "Effect of Load and Sliding Speed on Wear and Friction of Aluminum- Silicon Casting Alloy", International Journal of Scientific and Research Publications, Volume 2, Issue 3, March 2012.

[6]. GopalakrishnanElango,

BusunaKuppuswamyRaghunath,

KayaroganamPalanikumar,"Experimental

Analysis of the Wear Behavior of Hybrid Metal-Matrix Composites of LM25AL with Equal Volumes of $\mathrm{SiC}+\mathrm{Tio2}$ ", Materiali in Tehnologije / Materials and Technology Vol.48, Issue6, 2014.

[7]. N. Alnkoket. al. Dry Sliding Wear Behavior of Al2O3/SiC Particle Reinforced Aluminium Based MMCs Fabricated by Stir Casting Method, actaphysicapolonica a Vol. 124, 2013.

[8]. Vyjainto Kumar Ray, PayodharPadhi, B. B. Jha, Tapas Kumar Sahoo, "Wear Characteristics Of Pure Aluminium, Al-Alloy \& Al-Alumina Metal Mtrix Nano Composite In Dry Condition: Part-II", International Journal Of Research In 
Engineering And Technology, Volume: 04 Issue: 05 May2015.

[9]. N. Radhika, A. Vaishnavi, G.K. Chandran, "Optimisation of Dry Sliding Wear Process Parameters for Aluminium Hybrid Metal Matrix Composites, Tribology in Industry, Vol. 36, No. 2 (2014) 188-194

[10]. Reddappa H.N, Suresh K.R, Niranjan H.B, Satyanarayana K.G, Dry Sliding Friction And Wear Behavior Of Aluminum/Beryl Composites, International Journal Of Applied Engineering Research, Dindigul Volume 2, No 2, 2011.

[11]. S. Srivastava And S. Mohan, "Study of Wear and Friction of Al-Fe Metal Matrix Composite Produced by Liquid Metallurgical Method", Tribology in industry, Volume 33, No. 3, 2011

[12]. M. Usman et, al, Production and Characterisation of Aluminium Alloy - Bagasse Ash Composites, Journal of Mechanical and Civil Engineering, Volume 11, Issue 4, 2014, PP 38-44

[13]. Microstructural analysis and properties of Al$\mathrm{Cu} \mathrm{Mg/bagasse} \mathrm{ash} \mathrm{particulate} \mathrm{composites,}$ Journal of Alloys and Compounds Volume 497, Issues 1- 2, 14 May 2010, Pages 188-194. https://doi.org/10.1016/j.jallcom.2010.02.190

[14]. Kok M, Ozdin K. Wear resistance of aluminum alloy and its compositesreinforced by $\mathrm{Al} 2 \mathrm{O} 3$ particles. J Mater Process Technol 2007; 183:301-9.

[15]. Surappa MK, Prasad SV, Rohatgi PK. Wear and abrasion of cast $\mathrm{Al}$-alumina particle composites. Wear 1982; 77:295-302.

[16]. Yu Szu Ying, Ishii Hitoshi, Tohgo Keiichiro, Cho Young Tae, DiaoDongfeng. Temperature dependence of sliding wear behavior in $\mathrm{SiC}$ whisker or $\mathrm{SiC}$ particulate reinforced 6061 aluminum alloy composite. Wear 1997; 213:218.
[17]. Liang YN, Ma ZY, Li SZ, Li S, Bi J. Effect of particle size on wear behaviour of $\mathrm{SiC}$ particulate-reinforced aluminum alloy composites. J Mater SciLett 1995; 1:114-6.

[18]. Reda Y, Abdel-Karim R, Elmahallawi I. Improvements in mechanical and stress corrosion cracking properties in Al-alloy 7075 via retrogression and reaging. Mater Sci. Eng. A 2008; 485:468-75.

[19]. Clark RB, CoughranJr B, Traina I, Hernandez A, Scheck T, Etuk C, et al. On the correlation of mechanical and physical properties of 7075-T6 Al alloy. Eng. Fail Anal 2005; 12:520-6.

[20]. Kim SW, Kim DY, Kim WG, Woo KD. The study on characteristics of heat treatment of the direct squeeze cast 7075 wrought $\mathrm{Al}$ alloy. Mater Sci Eng. A 2001; 304-306:721-6.

[21]. Komai K, Minoshima K, Ryoson H. Tensile and fatigue fracture behavior and waterenvironment effects in a SiC-whisker/7075aluminum composite. Compos SciTechnol 1993; 46:59-66.

[22]. Liu Y, Rohatgi PK, Ray S. Tribological characteristics of aluminum-50 VolPct graphite composite. Metall Trans A 1993; 24 A: 151-9.

[23]. Rohatgi PK, Ray S, Liu Y. Tribological properties of metal matrix-graphite particle composites. Int Mater Rev 1992; 3(7):129-52.

[24]. Liu YB, Lim SC, Ray S, Rohatgi PK. Friction and wear of aluminium-graphite composites: the smearing process of graphite during sliding. Wear 1992; 159:201-5.

[25]. Rohatgi PK, Liu Y, Barr TL. Tribological behavior and surface analysis of tribo deformed Al Alloy-50 Pet graphite particle composites. Metal Trans A 1991; 22A:1435-41.

[26]. Mustafa SF. Casting of graphite Al-Si base composites. Can Metal Quart 1994; 33:259-64. 
[27]. Krishan BP, Rohatgi PK. Modification of Al-Si alloy melts containing graphite particle dispersions. Met Technol 1984; 11:41-4.

\section{Cite this article as :}

Maibusab, H K Shivanand, Madhu M. G., Shivaraj H.A. , Sumana B. G., "Evaluation of Wear Properties of Heat-treated Al 7075/Graphite Powder/Bagasse ash Hybrid Metal Matrix Composites", International Journal of Scientific Research in Science and Technology (IJSRST), Online ISSN : 2395-602X, Print ISSN : 2395-6011, Volume 6 Issue 3, pp. 201-210, May-June 2019. Available at doi : https://doi.org/10.32628/IJSRST1196338

Journal URL : http://ijsrst.com/IJSRST1196338 